\section{UCLA wins restraining order against activists}

The University of California, Los Angeles, (UCLA) succeeded last week in getting a temporary restraining order against five vociferous animal-rights activists, as well as organizations such as the Animal Liberation Front, who have claimed responsibility for various property crimes and threats against researchers.

The ruling stipulates that the activists must stay farther than $\mathbf{1 5}$ metres from researchers and remove the scientists' addresses from their websites. UCLA spokesman Phil Hampton called the ruling "a clear victory in the continuing process of UCLA protecting its researchers". The university will seek permanent restraining orders in a hearing on 12 March.

"They are trying to mix above-ground protestors that never do anything illegal in with the Animal Liberation Front and the underground organizations that have flooded homes and broken windows," says Jerry Vlasak, press officer for the North American Animal Liberation Press Office. "The two groups are completely separate; they don't know who each other are."

\section{Indonesia relents over bird-flu sample release}

Indonesia has resumed sending samples of the H5N1 bird-flu virus to the World Health Organization (WHO) after refusing to share samples for more than a year (see Nature 450, 1137; 2007). The US Centers for Disease Control and Prevention in Atlanta, Georgia, a WHO flu collaborating centre, has received a batch of samples from two patients - a woman who died earlier this month, and a girl hospitalized after her mother died of the disease.

The move is seen as an encouraging step towards ending a dispute in which Indonesia has argued that it is unfair that it should share samples without having access to affordable vaccines developed

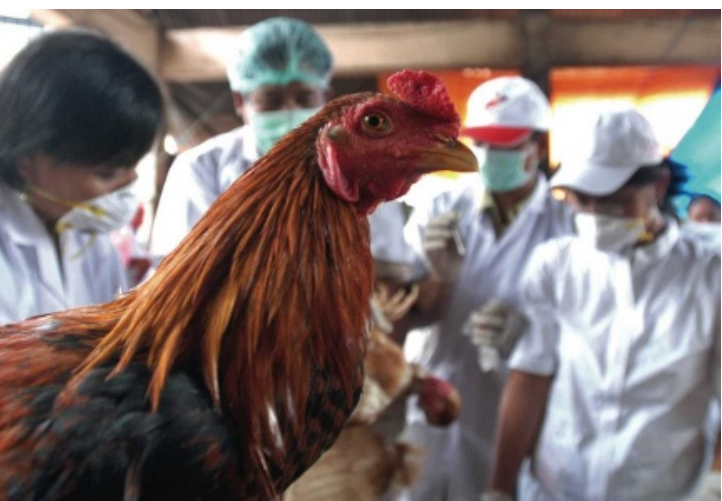

Health officials test birds at an Indonesian market.

\title{
Grey wolf no longer in danger, says US government
}

Calling its wolf programme a "remarkable

conservation success story", the US Fish and Wildlife

Service last week announced plans to remove grey

wolves (Canis lupus) in the northern Rocky Mountains

from the federal list of endangered species.

The decision comes 13 years after the first of 66

Canadian wolves were released in Yellowstone

National Park and central Idaho. Some 1,500

wolves, with at least 100 breeding pairs, now live

in Wyoming, Montana and Idaho.

These states will use hunting to manage the wolf population, which could set up a prolonged battle

between the ranchers and hunters who support

the plan, and environmentalists who fear

that wolf hunts could once again reduce

the population to perilous levels.

All three states have pledged to

maintain at least 150 wolves

and 15 breeding pairs, although

preliminary population targets

are between 900 and 1,250 wolves

according to the agency. Environmental

groups plan to challenge the decision in court

by countries using its samples. It wants a material transfer agreement to protect its rights over the samples.

The latest samples were sent under a draft agreement that allows the WHO to use them for research, but bans their commercial use without Indonesia's consent, says one source close to the negotiation.

\section{Biosafety lapses cost Texas A\&M \$1 million}

Texas A\&M University in College Station has agreed to pay a \$1-million fine for lapses in biosafety procedures. The failures resulted in lab workers becoming exposed to several deadly pathogens, including the organisms that cause brucellosis and $Q$ fever.

The US Centers for Disease Control and Prevention (CDC) in Atlanta, Georgia, shut down all biodefence-related research at the university last June, after the violations came to light. A\&M officials say they have since stepped up safety procedures and training for lab workers. The university had suggested it deserved a $\$ 10,000$ fine.

CDC officials will visit the university in March, and if the labs pass the inspection, biodefence research could resume shortly afterwards.

\section{US missile destroys toxic tank on spy satellite}

The United States has successfully destroyed an errant spy satellite, the Pentagon says.

The US National Reconnaissance Office lost contact with the satellite shortly after its launch in December 2006. The satellite contained 450 kilograms of toxic hydrazine propellant. "There was a reasonable chance that this hydrazine, if it fell in a populated area, would affect people," General James Cartwright, head of US Strategic Command, told reporters.

On 21 February, the USS Lake Erie fired a modified Standard Missile 3 - normally used as part of the US missile-defence system - to strike the satellite as it passed 247 kilometres over the Pacific Ocean. Four days later, Pentagon officials confirmed that the missile had successfully destroyed the fuel tank.

Critics say that the shot was meant to demonstrate US anti-satellite capabilities to China, which conducted its own test in 2007. Cartwright denies that charge.

\section{Florida adopts teaching of evolution in its schools}

The state of Florida can now officially teach evolution in its schools, following a 19 February vote.

The state's board of education voted 4-3 to include "the scientific theory of evolution" in its teaching standards. Evolution had not previously been mentioned by name in the biologycurriculum standards.

But the phrase "the scientific theory of" was added at the last minute, in order to garner enough votes to pass. One board member had proposed adding an amendment that would allow teachers to opt for exploring criticisms of evolution, but the amendment failed to go anywhere.

Still, science-education experts praised the standards change as a major step forward. 